\title{
CORPORATE SOCIAL RESPONSIBILITY DAN ZAKAT PERUSAHAAN DALAM PERSPEKTIF HUKUM EKONOMI ISLAM
}

\author{
A. Chairul Hadi \\ UIN Syarif Hidayatullah Jakarta \\ Jln. Ir. H. Djuanda No. 95 Ciputat, Tangerang Selatan \\ E-mail: chairul.hadi @uinjkt.ac.id
}

\begin{abstract}
Corporate Social Responsibility and Zakat of Company in the Perspective of Islamic Economic Law. Awareness of social responsibility by companies (corporate social responsibility) is increasing today. Almost every company has a board focusing on social services. In the Islamic banking industry, this social responsibility gets serious attention. The study revealed that besides allocating social funds, Islamic banks allocate funds for zakat of company as an obligation of a legal entity (syakhshiyyah hukmiyyah).
\end{abstract}

Keywords: CSR, zakat of company, Islamic finance, syakhshiyyah hukmiyyah

\begin{abstract}
Abstrak: Corporate Social Responsibility dan Zakat Perusahaan dalam Perspektif Hukum Ekonomi Islam. Kesadaran akan tanggung jawab sosial oleh perusahaan (Corporate Social Responsibility) atau yang biasa dikenal CSR dirasakan semakin meningkat saat ini. Hampir di setiap perusahaan, baik swasta maupun pemerintah terdapat badan atau bagian perusahaan yang mengurusi masalah sosial. Di dalam industri perbankan syariah, tanggung jawab sosial tersebut mendapat perhatian serius. Kajian ini mengungkapkan bahwa selain mengalokasikan dana sosial, bank syariah pun mengalokasikan dananya untuk zakat perusahaan atau zakat corporate sebagai wujud kewajiban badan hukum (syakhshiyyah hukmiyyah).
\end{abstract}

Kata Kunci: CSR, zakat perusahaan, keuangan syariah, syakhsiyyah hukmiyyah

\section{Pendahuluan}

Dalam konteks global, istilah CSR (Corporate Social Responsibility) mulai digunakan tahun 1970-an dan semakin populer setelah kehadiran buku Cannibals with Forks: The Triple Bottom Line in 21 $1^{\text {st }}$ Century Business (1998), karya John Elkington. Tiga komponen penting sustainable development, yakni economic growth, environmental protection, dan social equity, yang digagas The World Commission on Environment and Development (WCED) dalam Brundtland Report, dikemas oleh Elkington menjadi 3P, yaitu profit, planet, dan people. Perusahaan yang baik tidak hanya memburu keuntungan ekonomi belaka (profit), tapi juga harus memiliki kepedulian terhadap kelestarian lingkungan (planet), dan kesejahteraan masyarakat (people). ${ }^{1}$

Survei "The Millenium Poll on CSR" 1999 yang dilakukan oleh Environics Internasional (Toronto), Conference Board (New York), dan Prince of Wales

Naskah diterima: 2 Januari 2016; Direvisi: 13 Juni 2016; Disetujui untuk diterbitkan: 18 Juni 2016.

${ }^{1}$ Edi Suharto, "Audit CSR", Majalah Bisnis dan CSR, Vol.1, (April 2008), h. 91-92.
Business Leader Forum (London), diantara 25.000 responden di 23 negara menunjukkan bahwa dalam membentuk opini perusahaan, $60 \%$ mengatakan bahwa tanggung jawab sosial perusahaan yang paling berperan dibandingkan etika bisnis, perlakuan terhadap karyawan, dan dampak terhadap lingkungan. Sedangkan bagi 20 responden, berpendapat citra perusahaan yang akan paling mempengaruhi kesan mereka adalah faktorfaktor bisnis fundamental seperti faktor finansial, ukuran perusahaan, atau manajemen. Sisanya $20 \%$ responden berpendapat, sebagai masyarakat yang berada di sekitar perusahaan beroperasi, mereka ingin menghukum perusahaan yang dinilai tidak melakukan CSR, dengan tidak akan membeli produk atau menginformasikan kepada orang lain tentang kekurangan perusahaan tersebut. Sementara bagi perusahaan yang berkaitan dengan eksplorasi sumber daya alam, mereka menjawab akan mengajukan gugatan perwakilan (class action) terhadap implikasi adanya kegiatan pertambangan. ${ }^{2}$

Kesadaran tentang pentingnya mempraktikan CSR

${ }^{2}$ Data diakses pada 10 Oktober 2012 dari http://www.kutainegara. com/forum/ viewtopic.php?t= 1585 . 
ini menjadi tren global seiring dengan semakin maraknya kepedulian masyarakat global terhadap produkproduk ramah lingkungan dan diproduksi dengan memperhatikan kaidah-kaidah sosial dan prinsipprinsip hak asasi manusia (HAM). Sebagai contoh, boikot terhadap produk sepatu Nike oleh warga di negara Eropa dan Amerika Serikat terjadi ketika pabrik pembuat sepatu Nike di Asia dan Afrika diberitakan mempekerjakan anak di bawah umur. ${ }^{3}$

CSR dalam perspektif Islam merupakan konsekuensi inhern dari ajaran Islam itu sendiri. Tujuan dari syariat Islam (maqâshid al-syarîah) adalah maslahat. Bisnis adalah upaya untuk mewujudkan maslahat, bukan sekadar mencari keuntungan. Naqvy menyebutkan, kegiatan ekonomi dan bisnis dalam Islam dilandasi oleh aksioma tauhid, keseimbangan, dan pertanggungjawaban. Aksioma ini harus diimplemtasikan dalam seluruh aspek kegiatan ekonomi dan bisnis. Aksioma kesimbangan dan pertanggungjawaban misalnya akan membawa implikasi pada keseimbangan dan pertanggungjawaban antara jiwa dan raga, antara person dan keluarga, antara individu dan sosial, antara suatu masyarakat dan masyarakat lainnya. ${ }^{4}$

Di tanah air sendiri, CSR menguat setelah dinyatakan dengan tegas dalam UU PT No.40 Tahun 2007 yang menyebutkan, "Perseroan yang menjalankan kegiatan usahanya di bidang dan/atau berkaitan dengan sumber daya alam wajib melaksanakan tanggung jawab sosial dan lingkungan" (pasal 74 ayat 1). Peraturan lain yang menyentuh CSR adalah UU No. 25 Tahun 2007 Tentang Penanaman Modal, "setiap penanam modal berkewajiban melaksanakan tanggung jawab sosial perusahaan" (pasal 15b).

Kedua undang-undang tersebut dapat dikatakan sebagai payung hukum yang kuat dalam pelaksanaan CSR di Indonesia. Karena dalam UU tersebut, jelas disebutkan bahwa perusahaan wajib melaksanakan tanggung jawab sosialnya. Hal ini tentu saja mengubah paradigma awal yang sebelumnya berkembang di kalangan pengusaha bahwa pelaksanaan tanggung jawab sosial adalah semata-mata kerelaan perusahaan saja, karena sifat sosial dan suka relanya. Para pengusaha hanya menjalankan tanggung jawab sosial sebagai kepentingan publikasi demi membangun citra baik di masyarakat.

Peraturan tentang CSR yang lebih terperinci adalah

${ }^{3}$ Joko Setyono dan Muh. Ghafur, "Implementasi Corporate Social Responsibility (CSR) Bank Syariah dan Non-Syariah di Indonesia," Jurnal Ekonomi Islam, Vol. 3. No.1 (September 2007), h.3-5.

${ }^{4}$ Syeh Nawab Naqvy, Etika dan Ilmu Ekonomi Suatu Sintesa Islam, (Bandung: Mizan 1996), h, 17.
UU No. 19 Tahun 2003 tentang BUMN. Undangundang ini kemudian dijabarkan lebih jauh oleh Peraturan Menteri Negara BUMN No. 4 Tahun 2007 yang mengatur mulai dari besaran dana hingga tata cara pelaksanaan CSR. Seperti diketahui, CSR milik BUMN adalah PKBL (Program Kemitraan dan Bina Lingkungan). ${ }^{5}$

Adapun menurut UU No 21 Tahun 2008 Tentang Perbankan Syariah, bentuk badan hukum bank syariah adalah perseroan terbatas (pasal 7). Oleh karena itu, pelaksanaan CSR di perbankan syariah memiliki dasar hukum yang kuat, karena bank syariah tunduk pada undang-undang perusahaan. Selain itu, pada pasal 4 ayat (2) UU No. 21 Tahun 2008 tentang Perbankan Syariah, disebutkan bahwa bank syariah dan UUS dapat menjalankan fungsi sosial dalam bentuk lembaga baitul maal, yaitu menerima dana yang berasal dari zakat, infak, sedekah, hibah atau dana sosial lainnya dan menyalurkannya kepada organisasi pengelola zakat. ${ }^{6}$

Berkaitan dengan zakat, UU No. 38 Tahun 1999 tentang pengelolaan zakat menjelaskan bahwa perusahaan sebagai objek/harta dikenai zakat (bab IV pasal 11 ayat (2) bagian (b). ${ }^{7}$

Muktamar Internasional I tentang Zakat di Kuwait April 1984, merekomendasikan bahwa perusahaan wajib mengeluarkan zakat karena keberadaannya sebagai wadah usaha menjadi badan hukum (recht person), termasuk kedalam syakhsyan itibaran (badan hukum yang dianggap orang), atau menurut Musthafa' Ahmad Zarqa, perusahaan disebut syakhshiyyah hukmiyyah. ${ }^{8}$

Berdasarkan pemaparan di atas seolah-olah terdapat "dua kewajiban” perusahaan yaitu CSR dan Zakat Perusahaan. Artikel ini mengkaji lebih dalam bagaimana konsep dan implementasi CSR dan Zakat Perusahaan di Lembaga Keuangan Syariah. Tujuan kajian ini untuk mengetahui konsep CSR dan Zakat Perusahaan dalam hukum ekonomi Islam, persamaan dan perbedaan antara CSR dan Zakat Perusahaan serta bagaimana implementasi CSR di Lembaga Keuagan Syariah.

Kajian sebelumnya berkenaan dengan tulisan ini dilakukan oleh Raden Adi Wibowo (2006) dengan judul "Analisa Pelaporan Tanggung Jawab Sosial pada Total E \& P Indonesia" (2006), tulisan lainnya ialah karya Joko Setyono dan Muh. Ghafur (2007) yang berjudul "Implementasi CSR Bank Syariah dan Non-Syariah di Indonesia”.

\footnotetext{
${ }^{5}$ Edi Suharto, Majalah Bisnis dan CSR, h. 198-199.

${ }^{6}$ Andri Soemitra, Bank dan Lembaga Keuangan Syariah, (Jakarta: Kencana Pranada, 2009), h, 409.

${ }^{7}$ Didin Hafidhuddin, Zakat dalam Perekonomian Modern, (Jakarta: Gema Insani, 2002), h. 101.

${ }^{8}$ Didin Hafidhuddin, Zakat dalam Perekonomian Modern, h. 101.
} 
Selajutnya Ika Fitrianti (2008) dari Program Studi Manajemen Dakwah UIN Syarif Hidayatullah Jakarta, menulis CSR dengan judul "Strategi Pendistribusian dana CSR PT (Persero) Angkasa Pura II Kantor Cabang Utama dalam Upaya Mensejahterakan Masyarakat Sekitar Bandara Soekarno-Hatta" dan Rini Shitawati (2009) dari Program Studi Manajemen, Fakultas Ekonomi UIN Syarif Hidayatullah Jakarta, menulis "Analisis Kinerja Keuangan Sebelum dan Sesudah Menerapkan Tanggung Jawab Sosial (Studi Kasus pada Perusahaan yang Terdaftar di Bursa Efek Indonesia)". Hubungan CSR dan Zakat Perusahaan di Lembaga Keuangan Syariah belum pernah ada kaji, untuk itu penulis tertarik melakukan kajian tentang hal itu.

\section{Konsep dan Dasar Hukum CSR}

The World Business Council for Sustainable Development (WBCSD), lembaga internasional yang berdiri 1995 dan beranggotakan lebih dari 120 multinasional company dari 30 negara, dalam publikasinya Making Good Business Sense mendefinisikan CSR sebagai "Continuing commitment by business to behave ethically and contribute to economic development while improving the quality of life of the workforce and their families as well as of the local coomunity and society at large." Dalam terjemahan bebasnya, CSR adalah komitmen dunia usaha untuk terus-menerus bertindak secara etis beroperasi secara legal dan berkontribusi untuk peningkatan ekonomi, bersamaan dengan peningkatan kualitas hidup dari karyawan dan keluarganya sekaligus juga peningkatan kualitas komunitas lokal dan masyarakat secara lebih luas. ${ }^{9}$

Definisi lain dipaparkan oleh berbagai organisasi ${ }^{10}$, di antaranya International Finance Corporation yang menjelaskan bahwa CSR adalah komitmen dunia bisnis untuk memberi kontribusi terhadap pembangunan ekonomi berkelanjutan melalui kerja sama dengan karyawan, keluarga mereka, komunitas lokal dan masyarakat luas untuk meningkatkan kehidupan melalui cara-cara yang baik bagi bisnis maupun pembangunan. Institute of Chartered Accountants, England and Wales menyebutkan bahwa organisasi-organisasi pengelola bisnis mampu memberi dampak positif bagi masyarakat dan lingkungan, seraya memaksimalkan nilai bagi para pemegang saham (shareholders) mereka.

Sedangkan Canadian Government menegaskan bahwa kegiatan usaha yang mengintegrasikan ekonomi, lingkungan dan sosial ke dalam nilai, budaya, pengambilan

${ }^{9}$ Yusuf Wibisono, Membedah Konsep \& Aplikasi CSR, (Gresik: Fascho Publishing, 2007), h. 7.

${ }^{10}$ Edi Suharto, "Audit CSR", Majalah Bisnis \& CSR, Vol. I, No.5, (April 2008), h. 202-204. keputusan, strategi, dan operasi perusahaan yang dilakukan secara transparan dan bertanggung jawab untuk menciptakan masyarakat yang sehat dan bertanggung jawab untuk menciptakan masyarakat yang sehat dan berkembang itulah definisi CSR.

Pendapat lain dikemukan European Commision yang menegaskan bahwa CSR adalah konsep perusahaan yang mengintegrasikan perhatian terhadap sosial dan lingkungan dalam operasi bisnis dan interaksinya dengan pemangku kepentingan (stakeholders) berdasarkan prinsip kesukarelaan. CSR Asia juga memberikan definisi bahwa CSR adalah Komitmen perusahaan untuk beroperasi secara berkelanjutan berdasarkan prinsip ekonomi, sosial dan lingkungan, seraya menyeimbangkan beragam kepentingan para stakeholders.

CSR di Indonesia makin menguat setelah ditegaskan dalam UU PT No.40 Tahun 2007. Disebutkan, PT (Perusahaan Terbatas) yang menjalankan usaha di bidang dan/atau bersangkutan dengan sumber daya alam wajib menjalankan tanggung jawab sosial dan lingkungan (Pasal 74 ayat 1$).{ }^{11}$ UU PT tidak menyebutkan secara rinci berapa besaran biaya yang harus dikeluarkan perusahaan untuk CSR serta sanksi bagi yang melanggar. Pada ayat 2, 3, dan 4 hanya disebutkan bahwa CSR "dianggarkan dan diperhitungkan.

Peraturan lain yang menyentuh CSR adalah UU No.25 Tahun 2007 tentang Penanaman Modal. Pasal 15 (b) menyatakan bahwa "setiap penanam modal berkewajiban melaksanakan tanggung jawab sosial perusahaan". Meskipun UU ini telah mengatur sanksi secara terperinci terhadap badan usaha atau usaha perorangan yang mengabaikan CSR (pasal 34), UU ini hanya menjangkau investor asing dan belum mengatur secara tegas perihal CSR bagi perusahaan nasional.

Peraturan tentang CSR yang relatif lebih terperinci adalah UU No. 19 Tahun 2003 tentang BUMN. UU ini kemudian dijabarkan lebih jauh oleh Peraturan Menteri Negara BUMN No. 4 Tahun 2007 yang mengatur mulai dari besaran dana hingga tata cara pelaksaan CSR. Seperti kita ketahui, CSR milik BUMN adalah PKBL (Program Kemitraan dan Bina Lingkungan)

UUBUMN menyatakan, selain mencari keuntungan, peran BUMN adalah memberikan bimbingan bantuan secara aktif kepada pengusaha golongan lemah, koperasi, dan masyarakat. Selanjutnya, Permen Negara BUMN menjelaskan bahwa sumber dana PKBL berasal dari penyisihan laba bersih perusahaan sebesar $2 \%$ yang

${ }^{11}$ Edi Suharto, "Audit CSR", Majalah Bisnis \& CSR, Vol. I, No.5, (April 2008), h. 202-204. 
dapat digunakan untuk kegiatan tersebut. Penegasan peraturan ini, bahwa pihak-pihak yang berhak mendapat pinjaman adalah pengusaha beraset bersih maksimal Rp 200 juta atau beromset paling banyak Rp 1 miliar per tahun (pengusaha golongan lemah). ${ }^{12}$

Payung hukum lain yang tidak kalah pentingnya adalah Undang-Undang No. 21 Tahun 2008 tentang Perbankan Syariah. Disebutkan, "Bank Syariah dan UUS dapat menjalankan fungsi sosial dalam bentuk lembaga baitul maal, yaitu menerima dana yang berasal dari wakaf, infak, sedekah, hibah atau dana sosial lainnya dan menyalurkannya kepada organisasi pengelola zakat" (pasal 4 ayat 2). Dalam undang-undang ini, sangat jelas diterangkan bahwa bank syariah diberi amanah menjalankan fungsi sosial yang pada akhirnya harus melaksanakan CSR. Kehadiran UU perbankan ini memiliki dampak yang luas. Tidak hanya dilihat dari sektor makro, melainkan juga sektor mikro, bahkan penduduk miskin pun memiliki keterkaitan dengan kehadiran UU ini. Inilah kelebihan bank syariah dibandingkan bank konvensional. Perbankan syariah memiliki karakteristik unik yaitu berperan dalam mendukung sektor sosial di samping fungsi utamanya sebagai lembaga komersial.

Pengelolaan dana sosial perbankan, yang diperoleh dari zakat, infak, dan sedekah, serta dana sosial yang berasal dari penerimaan operasi (qardh) menjadi sangat potensial apabila dikelola dengan baik oleh perbankan syariah. Meskipun sifatnya sosial, pengelolaannya harus tetap profesional.

\section{Zakat Perusahaan}

Salah satu aspek penting dalam zakat adalah muzaki (subjek zakat, orang yang terkena kewajiban zakat, wajib zakat). Kajian tentang itu terdapat dalam bab mengenai "syarat-syarat wajib zakat". ${ }^{13}$ Pada hakikatnya, syaratsyarat wajib zakat terkait pada dua hal. Pertama, syarat pada individu muzaki itu sendiri. Kedua, syarat pada harta yang wajib dikeluarkan zakatnya.

Syarat-syarat wajib zakat yang berkaitan dengan diri muzaki, menurut Taqiyal-Din 'Ali Bakr, ada dua, yaitu Islam dan merdeka (bukan hamba sahaya). ${ }^{14}$ Kedua syarat ini ditambah Wahbah al-Zuhaylî dengan dua syarat lainnya, yakni: balig dan berakal. ${ }^{15}$ Sementara

${ }^{12}$ Edi Suharto, "Audit CSR", Majalah Bisnis \& CSR, Vol. I, No.5, h. 199.

${ }_{13}$ Taqiy al-Din Abu Baqkr ibn Muhammad al-Husyani, Kifayah al-Ahyar, (Bandung: al-Maarif, tt), h. 173.

${ }^{14}$ Taqiy al-Din Abu Baqkr ibn Muhammad al-Husyani, Kifayah al-Ahyar, h. 173.

15 Wahbah al-Zuhaylî, Zakat Kajian Berbagai Mazhab, syarat-syarat wajib zakat yang berkaitan dengan harta ada enam, yaitu: milik penuh; berkembang, cukup senisab, lebih dari kebutuhan biasa, bebas dari utang, dan berlaku setahun (haul). ${ }^{16}$

Namun demikian, syarat-syarat yang ada pada diri muzaki tidak secara otomatis menjadikan ia berkewajiban mengeluarkan zakat. Kewajibannya baru muncul apabila dipenuhi juga syarat-syarat yang terdapat pada harta. Artinya, untuk menetapkan kewajiban zakat harus diperhatikan dua kondisi: kondisi muzaki dan kondisi harta yang dimilikinya. Sementara itu, Wahbah al-Zuhaylî, membuat enam persyaratan muzaki terkena zakat, yaitu: 1) Islam; 2) balig-berakal; 3) bebas atau merdeka; 4) memiliki harta sampai nisab dan haul; 5) kepemilikan penuh (al-milkiyah al-tamma.li); dan 6) muzakki sudah dapat memenuhi kebutuhan pokoknya, sebelum ia membayar zakat. ${ }^{17}$

Masalah yang muncul kemudian, pertama, apabila muzaki dipersyaratkan beragama Islam, balih-berakal, dan merdeka, maka bagaimana halnya dengan orang kafir yang tinggal di negeri Muslim, anak kecil dan orang gila, serta para budak, padahal mereka memiliki harta yang dari segi syarat-syarat wajibnya telah terpenuhi kewajiban menunaikan zakat.

Kedua, apabila pada zaman dahulu, kepemilikan harta lebih bersifat individual, sementara pada zaman modern ini banyak kepemilikan harta bersifat kolektif seperti dalam bentuk perusahaan, yayasan, koperasi, dan lain-lain. Apakah semua bentuk kepemilikan kolektif itu terkena zakat? Tentang syarat muzaki beragama Islam, ijma ulama menetapkan kewajiban zakat bagi orang Muslim saja. ${ }^{18}$

Jumhur ulama berpendapat bahwa anak kecil, bukan saja wajib zakat fitrah, tetapi juga wajib zakat mal, bila anak tcrsebut memiliki harta yang wajib dizakati. Dalilnya hadis Nabi riwayat Tirmidzi dari 'Amr ibn Syu’aib yang berasal dari ayahnya, dari neneknya, kemudian dari nabi, "Niagakanlah harta anak yatim, sehingga (tidak habis) dimakan zakat." (H.r. al-Tirmidzi). Hadis tersebut menjelaskan bahwa harta anak yatim tetap wajib zakat, sebagaimana dilakukan 'Aisyah r.a., yang selalu mengeluarkan zakat dari harta anak-anak yatim yang diasuhnya.

Masalah kedua, apakah perusahaan wajib me-

Diterjemahkan oleh Agus Effendi, (Bandung: PT Remaja Rosdakarya, 1997), h. 100

16 Yusuf al-Qardhawi, Hukum Zakat, (Jakarta; Litera Antarnusa, 1993), h. 125-126

${ }_{17}$ Wahbah al-Zuhaylî, Al-Fiqh al-Islâmî wa Adillatuh, (Beirut: Dar Al-Fiqh al-Muashr, 1997), h.1797-1810.

${ }^{18}$ Wahbah al-Zuhaylî, Al-Fiqh al-Islàmî wa Adillatuh, h.1797-1810. 
ngeluarkan zakat atau tidak, dijawab Muktamar Internasional I tentang zakat di Kuwait, bahwa perusahaan wajib mengeluarkan zakat, karena keberadaan perusahaan sebagai wadah usaha menjadi badan hukum (reeht person). ${ }^{19}$ Perusahaan, menurut hasil muktamar tersebut, termasuk ke dalam syakhsh itibar (badan hukum yang dianggap orang) atau Syakhshiyyah hukmiyyah. Hal itu dikuatkan oleh Mustafa 'Ahmad alZarqa ${ }^{20}$ seperti disebutkan pada awal tulisan ini. Oleh karena itu, perusahaan termasuk muzaki atau subjek zakat.

Dalil yang dapat dijadikan rujukan berkenaan dengan zakat perusahaan ialah firman Allah Swt., "Hai, orang-orang yang beriman, nafkahkanlah (di jalan Allah) sebagian dari hasil usahamu yang baik-baik dan sebagian dari apa yang Kami keluarkan dari bumi untuk kamu ...."(Q.s. al-Baqarah: 267) sedangkan Hadis Nabi Muhammad Saw., "Rasulullah Saw. memerintahkan kepada kami agar mengeluarkan sedekah (zakat) dari segala yang hami maksudkan untuk dijual" (H.R. Abu Dawud). Hadis Nabi lainnya ialah yang diriwayatkan Imam Bukhari, dari Muhammad ibn 'Abd Allah al'Ansari dari bapaknya, ia berkata bahwa Abu Bakr r.a. telah menulis sebuah surat yang berisikan kewajiban yang diperintahkan Rasulullah Saw. “...janganlah disatukan (dikumpulkan) harta yang mula-mula terpisah. Sebaliknya, jangan pula dipisakkan harta yang pada mulanya bersatu, karena takut mengeluarkan zakat."(H.R. Bukhari).

Hadis Nabi tersebut, pada awalnya—berdasarkan asbabul-wurudnya, berkaitan dengan perkongsian dalam hewan ternak. Dengan dasar analogi (qiyas), dipergunakan pula untuk berbagai syirkdh (usaha bersama, perusahaan).

Tarif zakat perusahaan adalah sama dengan tarif zakat perdagangan yaitu $2,5 \%$. Besar tarif tersebut adalah untuk haul yang menggunakan tahun kamariyah. Apabila menggunakan tahun syamsiah, maka tarif zakatnya perlu penyesuaian. Pada Muktamar Zakat 1984, disepakati bahwa waktu bulan syamsiah lebih panjang dibanding tahun kamariyah, yaitu sekitar sebelas hari. Karena itu, pengguna tahun syamsiah harus memperhitungkan perbedaan tersebut. Akibatnya, tarif zakat perusahaan yang menggunakan hitungan syamsiah (365 hari) menjadi $2,578 \%$ yaitu $2,5 \% \mathrm{x}$ $365 / 354$ tidak dengan tarif 2,5\%.

Teknik perhitungan zakat perusahaan disesuaikan

19 Didin Hafidhuddin, Zakat dalam Perekonomian Modern, (Jakarta: Gema Insani 2002), h,101.

${ }^{20}$ Mustafa Ahmad al-Zarqâ, al-Fiqh al-Islâmî fì Tsawbih al-Jadîd, (Damaskus:1948), juz 3, h.101. dengan harta yang dimiliki perusahaan. Setiap perusahaan, paling tidak, memiliki tiga macam harta. Pertama, harta dalam bentuk barang, baik yang berupa sarana dan prasarana maupun yang berupa komoditas perdagangan. Kedua, harta dalam bentuk uang tunai, yang biasanya disimpan di bank. Ketiga, harta dalam bentuk piutang. Harta perusahaan yang wajib dizakati adalah ketiga bentuk harta tersebut, dikurangi harta dalam bentuk sarana dan prasarana dan kewajiban mendesak lainnya, seperti utang yang jatuh tempo atau yang harus dibayar saat itu juga. ${ }^{21}$

Zakat perusahaan adalah sebuah fenomena baru. Gejala ini dimulai dengan prakarsa para ulama, pengusaha, dan manajer Muslim modern untuk mengeluarkan zakat perusahaan. Boleh jadi, konsep ini mengikuti konsep pajak, yang membedakan antara pajak perseorangan (individual tax) dan pajak perusahaan (corporate tax).

Sebagai sebuah gejalabaru, paling tidakuntuk konteks Indonesia, wajar bila zakat perusahaan mendatangkan kontroversi. Menurut M. Dawam Rahardjo, ${ }^{22}$ wajib zakat itu tidak terkena pada perusahaan atau badan hukum, sebab perusahaan atau badan hukum tidak melakukan ibadah mahdah. Yang terkena zakat adalah orang yang bekerja atau karyawan pada perusahaan atau badan hukum tersebut. Perusahaan atau badan hukum, sangat terpuji apabila melakukan infak dan sedekah. Dengan demikian, perusahaan atau badan hukum tidak terkena ketentuan nisab dan tarif sebesar 2,5\% dari nilai kekayaan bersih (net worth).

Lain halnya apabila perusahaan itu milik perorangan, maka di sini zakat perusahaan itu identik dengan zakat pemiliknya. Menurutnya, ${ }^{23}$ jika diberlakukan kewajiban zakat atas pemilik dan perusahaanya, maka akan terjadi dua kali zakat. Selain itu masih perlu diperhitungkan dari mana tarif 2,5\% itu dihitung, dari laba bersih atau kekayaan bersih atau kedua-duanya?

Pemikiran M. Dawam Rahardjo ini berlawanan arus dengan kebanyakan ulama. Para ulama dalam Muktamar Internasional tersebut menganalogikan zakat perusahaan kepada zakat perdagangan karena dipandang dari aspek legal dan ekonomi. Kegiatan sebuah perusahaan intinya adalah berpijak pada kegiatan trading atau perdagangan. Oleh karena itu, nisabnya adalah sama dengan nisab zakat perdagangan yaitu 85 gram emas.

Perusahaan wajib mengeluarkan zakat, karena ke-

\footnotetext{
${ }^{21}$ Didin Hafidhuddin, Zakat dalam Perekonomian Modern, h, 102.

${ }^{22}$ M. Dawam Rahardjo, Islam dan Trasformasi Sosial-Ekonomi, (Jakarta : LSAF,1999), h.487.

${ }^{23}$ M. Dawam Rahardjo, Islam dan Trasformasi Sosial-Ekonomi, h.487.
} 
beradaan perusahaan adalah sebagai badan hukum (reeht person) atau yang dianggap orang. Karena itu, di antara individu tersebut kemudian timbul transaksi meminjam, menjual, berhubungan dengan pihak luar, dan juga menjalin kerjasama. Segala kewajiban dan hasil akhirnya pun dinikmati secara bersama-sama, termasuk di dalamnya kewajiban kepada Allah Swt. dalam bentuk zakat. ${ }^{24}$

\section{Implementasi CSR Bank Syariah Mandiri (BSM)}

BSM menyakini bahwa tanggung jawab sosial perusahaan (Corporate Social Responsibility/CSR) merupakan hal penting dalam mendukung tumbuh kembangnya bank. Oleh karena itu, BSM menempatkan kegiatan tersebut dalam kerangka upaya perusahaan untuk mencapai keberlanjutan (sustainability) dalam jangka panjang. Arti dari bisnis yang berkelanjutan (sustainable business) adalah senantisa memberikan kinerja yang maksimal dan optimal untuk para pemegang saham, tetapi juga secara menyeluruh berusaha untuk memberikan kontribusi yang maksimal dalam aspek sosial dan lingkungan. ${ }^{25}$

Melalui pendekatan triple bottim lines yang meliputi kinerja ekonomi (economic indocators), kinerja lingkungan (environmental indicators), dan kinerja sosial (social indicators) diharapkan keberadaan BSM tidak hanya bermanfaat bagi para pemangku kepentingan (stakeholders) yang lebih luas yaitu masyarakat dan lingkungan. Dengan kata lain, BSM berusaha untuk memaksimalkan laba perusahaan (profit) selaras dengan tujuan untuk memberikan kemanfaatan yang sebesarbesarnya bagi masyarakat (people) dan lingkungan (planet). BSM meyakini bahwa dengan pendekatan yang menyeluruh ini akan mendukung tercapainya tujuan pembangunan yang berkelanjutan (sustainable development), yaitu kegiatan pembangunan yang dilakukan untuk memenuhi kebutuhan generasi sekarang tanpa mengorbankan kepentingan generasi mendatang. ${ }^{26}$

Dengan kepercayaan bahwa perusahaan, masyarakat dan lingkungan bisa berjalan seiring dalam mencapai tujuan yang sama, BSM menempatkan kegiatan CSR sebagai inti (core strategy) dan menjadikannya sebagai sumber inovasi dan efisiensi untuk meningkatkan keunggulan bersaing (competitive advantage) perusahaan. Hal ini berbeda dengan perusahaan yang

\footnotetext{
${ }^{24}$ Didin Hafidhuddin, Zakat dalam Perekonomian Modern, h,101.

${ }^{25}$ PT Bank Syariah Mandiri, "Grater Way for Greater Indonesia", Laporan Tahunan 2012, h. 238.

${ }^{26}$ PT Bank Syariah Mandiri, "Grater Way for Greater Indonesia”, Laporan Tahunan 2012, h. 238.
}

menempatkan kegiatan CSR sebagai batas kegiatan donasi yang dilakukan oleh perusahaan (corporate philantrophy). ${ }^{27}$

Dalam mengimplementasikan pelaksanaan CSR, BSM bersinergi dengan Yayasan Bangun Sejahtera Mitra Umat (BSM Umat). Keberadaan BSM Umat dikukuhkan sebagai Lembaga Amil Zakat Nasional (Laznas) oleh pemerintah melalui SK Menteri Agama No. 406 tahun 2002 tanggal 17 September 2002. BSM menjalin kerjasama dengan Laznas BSM/ Lembaga Mitra dalam penyaluran dana zakat perusahaan dan pelaksanaan program-program yang bersifat kemanuisaan. Acuan kerja pelaksanaan program CSR melalui Perjanjian Kerja Sama (PKS) BSM dan Laznas BSM No. 12/410-PKS/DIR; No. 09/001/LAZBSM/ DIR tanggal 12 November 2010 tentang Penyaluran Zakat dan Dana Program. ${ }^{28}$

Dalam penyaluran dan CSR, Bank Syariah Mandiri menyalurkannya melalui Laznas BSM. Penyaluran dana CSR ini dilaksanakan berdasarkan prosedur yang berlaku dengan menggunakan sistem anggaran. Sebelum tahun pelaksanaan kegiatan CSR, Laznas BSM sudah membuat proyeksi kegiatan CSR apa yang akan dilaksanakan pada tahun yang akan datang. Proyeksi kegiatan CSR ini dipresentasikan kepada pihak Bank Syariah Mandiri dalam rapat anggaran untuk ditentukan persetujuannya. Rapat anggaran ini juga menentukan jumlah dana yang akan disalurkan oleh Bank Syariah Mandiri melalui Laznas BSM. ${ }^{29}$

BSM secara konsisten melaksanakan kegiatan Corporate Sosial Responsibility (CSR) sejak tahun 2002 sebagai wujud kepedulian perusahaan sekaligus apresiasi kepada masyarakat yang telah memberikan kepercayaan dan dukungan atas proses bisnis perbankan syariah. Keberlangsungan bisnis bank tidak lepas dari partisipasi masyarakat dalam menyambut berbagai produk perbankan syariah dan layanan yang ditawarkan oleh bank. ${ }^{30}$

Sebagai bentuk komitmen perusahaan terhadap kegiatan-kegiatan sosial. Bank Syariah Mandiri menyediakan anggaran yang wajar dan memadai untuk mendukung program-program CSR yang secara konsisten. Pelaksanaan program CSR memiliki dua sumber dana, yakni dana zakat dan dana kebajikan.

\footnotetext{
${ }^{27}$ PT Bank Syariah Mandiri, "Grater Way for Greater Indonesia”, Laporan Tahunan 2012, h. 238.

${ }^{28}$ PT Bank Syariah Mandiri, "Grater Way for Greater Indonesia”, Laporan Tahunan 2012, h. 238.

${ }^{29}$ Wawancara dengan Ismaya Aji, Bagian CSD Bank Syariah Mandiri, Jakarta, 7 November 2013.

${ }^{30}$ Wawancara dengan Ismaya Aji, Bagian CSD Bank Syariah Mandiri, Jakarta, 7 November 2013.
} 
Dana zakat bersumber dari zakat perusahaan (BSM), ditambah zakat nasabah dan umum, serta zakat pegawai BSM. Zakat perusahaan merupakan liabilitas zakat bank yang dihitung dari laba sebelum pajak yang didapatkan perusahaan. ${ }^{31}$ Zakat umum didapatkan dari nasabah BSM atau masyarakat umum yang ingin menyalurkan zakatnya melalui BSM. Sedangkan zakat pegawai BSM adalah zakat yang diperoleh dari 2,5\% gaji karyawan BSM setiap bulannya. ${ }^{32}$

Sumber Dana ZIS 2012

\begin{tabular}{cll}
\hline No & Sumber Dana & Jumlah (Rp) \\
\hline 1 & $\begin{array}{l}\text { Zakat Korporat-Perusahaan } \\
\text { BSM }\end{array}$ & 14.582 .880 .512 \\
\hline 2 & Zakat Pegawai BSM & 14.912 .269 .051 \\
\hline 3 & Zakat Nasabah BSM & 7.100 .264 .051 \\
\hline 4 & Zakat Masyarakat Umum & 5.320 .202 .505 \\
\hline & Total & 41.915 .616 .328 \\
\hline
\end{tabular}

Sumber dana lainnya ialah denda, pendapatan nonhalal, dan dana sosial lainnya. Denda didapatkan dari akumulasi denda-denda administrasi nasabah. Pendapatan nonhalal diperoleh dari dana-dana yang tidak sesuai syariah seperti bunga bank, dan tidak diakui sebagai pendapatan perusahaan. Dana sosial lainnya didapatkan dari dana-dana di luar denda dan pendapatan nonhalal, yang tidak diakui sebagai pendapatan perusahaan.

Dana sosial lainnya didapatkan dari dana-dana di luar denda dan pendapatan nonhalal, yang tidak diakui sebagai pendapatan perusahaan. Dana kebijakan atau dana sosial tidak boleh digunakan untuk kegiatan konsumtif karena berasal dari pendapatan nonhalal. ${ }^{33}$ Sumber dana dan penyalur CSR BSM terlihat pada tabel berikut:

Sumber Dana Kebajikan BSM 2012

\begin{tabular}{clll}
\hline No & Sumber Dana & $\mathbf{2 0 1 1}$ & $\mathbf{2 0 1 2}$ \\
\hline 1 & Denda & $637.436-351$ & 830.667 .606 \\
\hline 2 & Sumbangan Hibah & & 8.472 .451 \\
\hline 3 & Penerimaan & 610.212 .906 & 453.611 .371 \\
& Nonhalal & & \\
\hline 4 & Dana Sosial lainnya & 1.183 .423 .316 & 481.628 .334 \\
\hline
\end{tabular}

${ }^{31}$ PT Bank Syariah Mandiri, "Grater Way for Greater Indonesia", Laporan Tahunan 2012, h. 233.

32 PT Bank Syariah Mandiri, "Grater Way for Greater Indonesia", Laporan Tahunan 2012, h. 240.

${ }_{33}$ PT Bank Syariah Mandiri, "Grater Way for Greater Indonesia”, Laporan Tahunan 2012, h. 386
Dana CSR Bank Syariah Mandiri Tahun 2012

\begin{tabular}{lllll}
\hline Dana Zakat & $\begin{array}{l}\text { Dana } \\
\text { Kebajikan }\end{array}$ & Jumlah Dana CSR & $\begin{array}{l}\text { Dana CSR } \\
\text { Disalurkan }\end{array}$ & $\begin{array}{l}\text { Persentase } \\
\text { Penyaluran }\end{array}$ \\
\hline 41.915 .616 .328 & 1.814 .450 .975 & 19.905 .591 .321 & 26.490 .000 .000 & $87 \%$ \\
\hline
\end{tabular}

Pada 2012, dana zakat yang tersalurkan adalah sebesar Rp 22,24 miliar, dan dana kebajikan yang tersalurkan adalah sebesar $\mathrm{Rp} 1.774 .397 .852$, atau $72,99 \%$ dan saldo tahun 2011 sebesar Rp 2.431.072.583. sehingga secara keseluruhan dana CSR yang disalurkan pada tahun 2012 adalah sebesar Rp 26.49 miliar. Adapun penyaluran dana CSR Bank Syariah Mandiri pada 2012, melalui program CSR terkait sosial kemasyarakatan dan lingkungan.

Adapun program CSR BSM meliputi, ${ }^{34}$ pertama, pengembangan ekonomi umat/mitra umat. Pelaksanaan CSR bidang pengembangan ekonomi umat bertujuan untuk menciptakan kemandirian masyarakat dalam mencapai peningkatan kesejahteraan dalam jangka panjang. Program CSR bidang ini diwujudkan dalam pemberian bantuan permodalan, sarana kerja, dan sebagainya. Beberapa kegiatan yang telah dilaksanakan pada tahun 2012 antara lain berupa bantuan pemberdayaan ekonomi masyarakat sekitar Jabotabek (103 orang), bantuan modal kerja outlet, modal kerja, dan renovasi pedagang gerobak, bantuan pelatihan dan permodalan LKMS. Dana yang telah dialokasikan untuk program kemitraan ini Rp 2, 65 miliar.

Kedua, program pengembangan pendidikan dan pelatihan. Program CSR BSM di bidang pengembangan pendidikan selama 2012 menggunakan dana sebesar Rp 9.249.672.228. Program difokuskan pada peningkatan kualitas pendidikan dan bantuan sarana pendidikan, yang diwujudkan dalam bentuk pemberian beasiswa kepada siswa dari keluarga kurang mampu sebanyak 4.000 siswa dan 445 mahasiswa. Kegiatan dilaksanakan secara menyeluruh, baik di lingkungan kantor pusat BSM di Jakarta maupun kantor cabang di seluruh pelosok negeri.

Ketiga, program sosial/budaya. Program CSR BSM di bidang sosial/budaya selama 2012 menggunakan dana sebesar Rp 1.990.000.000,00, meningkat dibanding realisasi tahun 2009 sebesar Rp 436.420.000,00. Program CSR untuk bidang sosial/budaya diwujudkan dalam bentuk santunan duafa, santunan Ramadan, bantuan korban bencana alam, bantuan pembangunan, renovasi masjid dan madrasah, dan program-program lainnya.

Keempat, program perbaikan kesehatan masyarakat dan lingkungan. Program CSR BSM di bidang

\footnotetext{
${ }^{34}$ PT Bank Syariah Mandiri, "Grater Way for Greater Indonesia",
} Laporan Tahunan 2012, h. 240-255 
perbaikan kesehatan selama 2012 menggunakan dana sebesar Rp 44.280.000,00 meningkat dibanding tahun 2009 sebesar Rp. 41.850.000,00. Program CSR untuk bidang ini difokuskan pada peningkatan kualitas kesehatan masyarakat sekitar yang diwujudkan dalam bentuk bantuan kesehatan dan pelaksanaan donor darah Laznas BSM.

\section{Implementasi CSR Bank Muamalat Indonesia (BMI)}

Sebagai bank pertama murni syariah, Bank Muamalat berkomitmen untuk menghadirkan lanyanan perbankan yang tidak hanya mematuhi kaidah syariah juga kompetitif dan akseptabel bagi masyarakat. Selain untuk menerapkan kaidah syariah demi kemaslahatan umat, Bank Muamalah juga senantiasa berusaha menerapkan good corporate governance melalui program CSR.

Bank Muamalat Indonesia membentuk unit khusus untuk mengelola dana CSR, yaitu Baitul Maal Muamalat (BMM). BMM adalah lembaga nonprofit yang didirikan oleh Bank Muamalat, berkonsentrasi pada program community development dan Islamic social security fund.

Berbeda dengan BSM, Bank Muamalah tidak menyebutkan "Zakat Perusahaan" dalam laporan keuangan perusahaan. Hal ini mengindikasikan bahwa Bank Muamalat tidak mengalokasikan "zakat perusahaan". Suber dana utama CSR bank ini adalah Zakat, infak, dan sedekah pegawai dan masyarakat Muslim, denda, dan dana pendapat nonhalal. ${ }^{35}$

Demi mendukung sukses program CSR, Bank Muamalat bekerja sama dengan lembaga Baitul Maal Muamalat (BMM). Dana yang dihimpun pada 2012 sebanyak Rp 34.8 miliar dengan program CSR antara lain, ${ }^{36}$ pertama, program rutin keagamaan dalam bentuk "Program Berbagi Cahaya Ramadan" dan "Berbagi Cahaya Kurban". Kedua program ini berupa santunan kepeluan Ramadan dan Kurban dengan alokasi anggaran Rp 3,4 milyar untuk berbagi "Program Cahaya Ramadan" dan "Program Berbagi Cahaya Kurban” sebanyak Rp 592.014.856.

Kedua, program Pemberdayaan umat. Terdapat beberapa program pemberdayaan umat antara lain, 1) pemberdayaan Baitul Mall atau Program KUM3 (Komunitas Usaha Mikro Muamalat) merupakan program pemberdayaan ekonomi keluarga miskin di Indonesia dengan masjid sebagai basis pembinaannya. Kegiatan-

\footnotetext{
${ }^{35}$ Bank Muamalah Indonesia, "The Great Leap Forward”, Laporan Tahunan 2012.

${ }^{36}$ Bank Muamalah Indonesia, "The Great Leap Forward”, Laporan Tahunan 2012.
}

nya dalam bentuk pemberian bantuan pinjaman qardh, pembinaan keterampilan usaha, kedisiplinan ibadah, berinfak, dan menabung. Program ini menjangkau 22 Provinsi di Indonesia dengan jumlah masjid yang berjumlah 202 masjid sampai akhir 2008. Peserta pada 2012 mencapai 4.686 peserta, dan dana yang dikelola

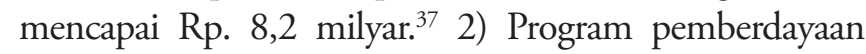
Koperasi Jasa Keuangan Syariah (KJKS), dana bergulir syariah dan BMT-esyar i LKMS.

Ketiga, program pendidikan yaitu berupa pemberian beasiswa dan pembinaan anak yatim piatu yang berprestasi dan anak dari keluarga prasejahtra. Dana yang terserap untuk program ini mencapai $\mathrm{Rp}$ 2,1 milyar. Pada 2012 mencakup, 1) Program Bidang Sosial; Program ini meliputi santunan tunai, ATM (Aksi Tanggap Muamalat) dan KSM (komunitas Sehat Muamalat); 2) Program Khusus seperti program pemberdayaan anak yatim piatu.

\section{Analisis Pelaksanaan CSR dan Zakat Perusahaan Perbankan Syariah}

Selain bertanggung jawab untuk menjalankan perusahaan kepada pemegang saham, direksi, dan komisaris serta jajarannya juga bertanggung jawab kepada stakeholders lainnya, termasuk karyawan dan masyarakat. Perusahaan memiliki tanggung jawab untuk mematuhi peraturan hukum dan ketentuan atau peraturan yang berlaku, termasuk tanggapan lingkungan di mana perusahaaan berada ${ }^{38}$.

Tanggung jawab menjadi misi hidup setiap Muslim, karena ia hanya dapat menjumpai Yang Mahabenar yaitu Allah dalam keadaan rida dan diridai, yaitu manakala menepati amanat yang telah dipikulkan kepadanya. Sifat ini akan membentuk kredibilitas yang tinggi dan sikap penuh tanggung jawab pada setiap individu Muslim maupun kumpulan individu karena dilandasi oleh saling percaya antar anggotanya. Sifat amanah memainkan peranan fundamental dalam ekonomi dan bisnis, karena tanpa kredibilitas dan tanggung jawab, kehidupan ekonomi dan bisnis akan hancur. ${ }^{39}$

Perbankan syariah sebagai salah satu institusi keuangan yang berlandaskan pada nilai-nilai Islam selayaknya mengedepankan etika, moral dan pertanggungjawaban sosial dalam menjalankan aktivitasnya. Terkait dengan karakteristik bank syariah pada dasarnya memiliki peran

\footnotetext{
${ }^{37}$ Bank Muamalah Indonesia, “The Great Leap Forward”, Laporan Tahunan 2012.

${ }^{38}$ Muhammad Syakir Sula, Asuransi Syariah; Life and General, (Jakarta: PT Gema Insani Press, 2004), h. 60.

${ }^{39}$ Adiwarman Karim, Ekonomi Mikro Islam (Jakarta: PT IIT, 2002), h. 19
} 
sosial yang sangat penting. Pentingnya peran sosial tersebut selaras dengan ketentuan perundang-undangan bank syariah.

Konsep CSR sendiri merupakan suatu komitmen yang secara alami dimiliki oleh suatu institusi Islam khususnya bank syariah yang tujuan pendiriannya diarahkan pada penerapan nilai-nilai persaudaraan, persamaan sosial, dan pemeratan distribusi pendapatan di masyarakat. Pembahasan tentang distribusi pendapatan tidak lepas dari pembahasan tentang konsep distribusi.

M.A Mannan ${ }^{40}$ menyebutkan bahwa teori distribusi merupakan suatu teori yang menetapkan harga jasa produksi. Untuk itu, ia berusaha menemukan nilai jasa dari berbagai faktor produksi dan nilai-nilai etik tentang pemilikan faktor-faktor produksi. Lebih lanjut M. Anas Zarqa dalam buku Keadilan Distributif dalam Ekonomi Islam sebagaimana dikutif Euis Amaliaa ${ }^{41}$ mengemukakan beberapa prinsip distribusi dalam ekonomi Islam, yaitu: pemenuhan kebutuhan bagi semua makhluk yang menimbulkan efek positif bagi pemberi itu. Contoh prinsip itu ialah zakat, selain dapat membersihkan diri dan harta muzaki juga meningkatkan keimanan dan menumbuhkan kebiasaan berbagi dengan orang lain, menciptakan kebaikan di antara semua orang antara yang kaya dan miskin, mengurangi kesenjangan pendapatan dan kekayaan, pemanfaatan lebih baik terhadap sumber daya alam dan aset tetap serta memberikan harapan pada orang lain melalui pemberian.

Inilah letak pentingnya keadilan distribusi dalam Islam. Karena harta kekayaan yang terpusat pada suatu golongan tertentu akan berdampak buruk, baik dari segi sosial maupun perilaku ekonomi. Bagaimana pun harus disadari bahwa didalam harta setiap muslim terdapat harta muslim yang lain.

Islam menekankan pada kesetaraan, sehingga sangat perlu untuk melakukan distribusi yang adil. Dampak sosial yang mungkin ditimbulkan karena ketidakadilan ini misalnya dengan adanya jurang pemisah antara si kaya dan si miskin yang pada akhirnya menimbulkan kedengkian si miskin yang dapat berdampak pada peningkatan kasus kriminalitas. Dampak ekonomi yang timbul adalah inflasi karena sikap konsumtif dari pihak-pihak yang harta kekayaan terpusat pada mereka. Apabila disalurkan dengan baik, tentu saja

${ }^{40}$ M.A. Mannan, Teori dan Praktik Ekonomi Islam, Edisi Lisensi (Yogyakarta: Dana Bhakti Wakaf, 1993), h. 113.

${ }^{41}$ Euis Amalia, Keadilan Distributif dalam Ekonomi Islam, Penguatan Peran LKM dan UKM di Indonesia (Jakarta: PT Rajagrafindo Persada, 2009), h. 118-119. akan membawa dampak yang baik pada berbagai aspek.

Kegiatan CSR yang dilakukan oleh Bank Syariah baik BSM dan BMI merupakan perwujudan atas komitmen perusahaan yang teguh dalam menerapkan prinsipprinsip syariah yang di dalamnya terkandung ajaran untuk membina hubungan yang harmonis dengan masyarakat sekitar. Untuk itu secara berkesinambungan perusahaan mengalokasikan dana untuk berbagai program sosial baik dalam bentuk zakat, infak, dan sedekah.

Perbankan syariah selalu berupaya untuk peduli terhadap sesama dengan ikut mengentaskan masalahmasalah sosial yang dihadapi masyarakat. Dalam ajaran Islam, prinsip kepedulian sosial ini diwujudkan melalui konsep zakat, infak, dan sedekah. Umat diharuskan harus bertanggung jawab secara material terhadap kemiskinan yang ada di lingkungannya. Lebih jauh konsep zakat ditujukan untuk memelihara agama, akal, jiwa, keturunan, dan harta.

Sebagian lembaga keuangan syariah yang melakukan kegiatan bisnis berdasarkan prinsip syariah Islam, BSM menyisihkan sebagian $(2,5 \%)$ dari laba perusahaan sebagai pembayaran zakat, bukan hanya karena adanya aturan (UU Pengelolaan Zakat No. 23 2011) bahwa perusahaan sebagai lembaga yang wajib mengeluarkan zakat (muzaki) tapi lebih daripada itu adanya usaha BSM dalam meraih "keberkahan" sebagai lembaga keuangan syariah. ${ }^{42}$

Sama seperti BSM, Bank Muamalah telah menjadikan CSR sebagai bagian yang penting dalam perusahaan walaupun belum mewajibkan adanya "zakat perusahan”. BMI menjalankan fungsi sosialnya dengan mengalokasiakan dana CSR yang bersumber dari ZIS karyawan, nasabah dan pendapatan bank.

Perusahaan merupakan syakhshiyyah itibariyyah atau recht person, yakni badan yang dianggap seperti orang, karena ia dapat bertindak layaknya manusia. Sebagai contoh, perusahaan dapat memiliki aset dan kekayaan, membeli atau menjual aset, melakukan transaksi bisnis dan perdagangan, menuntut dan dituntut di pengadilan, dan sebagainya. Sehingga secara fikih, perusahaan termasuk objek zakat.

Kewajiban zakat perusahaan telah dinyatakan dalam undang-undang. Berdasarkan Pasal 1 UU No 23/2011 tentang Pengelolaan Zakat, dinyatakan bahwa yang termasuk muzaki adalah seorang muslim atau badan usaha yang berkewajiban menunaikan zakat. Kemudian

\footnotetext{
${ }^{42}$ Wawancara Pribadi dengan Ismaya Aji, Bagian CSD BSM, 7 November 2012
} 
pada pasal 4 ayat 2 poin (g) juga disebutkan bahwa perindustrian merupakan salah satu sumber harta objek zakat, yaitu zakat harta. Dengan demikian, baik secara fikih maupun secara aturan hukum positif di negeri ini, perusahaan yang telah memenuhi syarat, wajib mengeluarkan zakatnya, di samping zakat para direksi, komisaris, dan karyawannya.

Namun harus diakui bahwa, kewajiban zakat bagi perusahaan yang dipandang sebagai syakhsiah hukmiah, masih mengandung perbedaan/khilafiayah di kalangan ulama kontemporer. Perbedaan pendapat ini disebabkan karena memang lembaga badan hukum seperti perusahaan itu memang belum ada secara formal dalam wacana fikih klasik. Meskipun ada semacam khilafiyah, tetapi umumnya ulama kontemporer yang mendalami masalah zakat, mengkategorikan lembaga badan hukum itu sebagai menerima hukum taklif dari segi kekayaan yang dimilikinya, karena pada hakikatnya badan hukum tersebut merupakan gabungan dari para pemegang saham yang masing-masing terkena taklif. Justru itu, ia dapat dinyatakan sebagai syakhsyiyah hukmiyah yang bertanggung jawab dalam pengelolaan perusahaan.

Wahbah al-Zuhaylî dalam karyanya "Al-Fiqh alIslâmî wa Adillatuh" menuliskan, fikh Islam mengakui apa yang disebut dalam hukum positif sebagai syakhshiyyah hukmiyyah atau syakhshiyah itibariyyah/mánawiyyah atau mujarradah (badan hukum) dengan mengakui keberadaannya sebagai lembaga-lembaga umum, seperti yayasan, perhimpunan, dan perusahaan, sebagai syakhshiyyah (badan) yang menyerupai syakhshiyyah manusia pada segi kecakapan, mempunyai hak-hak, menjalankan kewajiban-kewajiban, dan memikul tanggung jawab yang berdiri sendiri secara umum". ${ }^{43}$ Sejalan dengan Wahbah, Mustafa Ahmad Zarqa dalam kitab "Madkhal al-Figh al-'am" mengatakan, "Fikih Islam mengakui adanya syakhsyiyah hukmiyah atau I'tibariyah (badan hukum). ${ }^{44}$

Sebagian ulama lainya, seperti Syauqi Ismail Syahatah, Ahmad Ali Abdullah, dan Ahmad al-Shadiq al-Basyir juga berpendapat, badan usaha, baik milik swasta maupun milik negara, merupakan subjek hukum yang berdiri sendiri dalam hal harta. Oleh karena itu, apabila telah terpenuhi nisab dan haul, maka badan hukum usaha dikenakan kewajiban zakat. Argumen yang mereka kemukakan ialah, ${ }^{45} 1$ ), badan usaha

\footnotetext{
${ }^{43}$ Wahbah al-Zuhayli, Figh al-Islamy wa Adillatuhu, h. 256.

${ }^{44}$ Mustafa Ahmad al-Zarqâ, al-Fiqh al-Islamy Fi Tsaubihi al-jadid, (Damascus: Dar al- Fikr, 1948), h. 77.

${ }^{45}$ Abdurrahman Dahlan, "Kewajiban Zakat Badan Hukum Perusahaan”, Makalah Diskusi Dosen FSH, h. 8
}

merupakan badan hukum yang memiliki kelayakan/ kecakapan untuk menerima hak dan memikul kewajiban yang berdiri sendiri; 2) Kepemilikan pada kekayaan badan usaha sebagai badan hukum terletak pada badan usaha itu sendiri, bukan pada pemegang saham. Oleh karena itu, badan usaha dapat disebut sebagai mukalaf, baik ditinjau dari segi syarak maupun perundang-undangan. Sebagai mukalaf, badan usaha dibebani kewajiban zakat secara langsung, bukan sebagai wakil dari pemegang saham; 3) Kewajiban zakat berkaitan dengan harta, sehingga tidak diperlukan persyaratan taklif. Karena itu, kewajiban zakat pada badan usaha sebagai badan hukum sama dengan kewajiban zakat pada harta anak-anak dan orang gila. Kewajiban zakat (zimmah) pada kedua orang tersebut tidak tergantung pada perbuatannya, tetapi pada hartanya. Jumhur ulama sepakat bahwa badan usaha memiliki tanggung jawab atas kekayaan (zimmah maliyah) sebagaimana halnya anak-anak dan orang gila yang juga memiliki tanggung jawab atas kekayaan; 4) Kewajiban zakat pada badan usaha sejalan dengan prinsip kemaslahatan zakat, yaitu untuk menutupi kebutuhan fakir miskin dan mensucikan harta. Kemaslahatan tersebut terdapat pada tujuan kewajiban zakat pada anak-anak dan orang gila; 5) Kewajiban zakat tidak semata-mata berfungsi sebagai ibadah, tetapi juga muamalah. Karena itu kewajiban zakat tidak hanya berlaku bagi mukalaf.

Berbeda dengan pandangan para ulama di atas, ada juga berpendapat bahwa berdasarkan kepemilikannya, perusahaan swasta dengan berbagai bentuknya, pada hakikatnya adalah milik subjek hukum pribadi (natuurlijke persoon/ natural person) yaitu manusia pribadi. Argumen yang dapat dikemukakan, antara lain, 1) meskipun badan hukum usaha merupakan subjek hukum yang memiliki kelayakan untuk menerima hak dan memikul kewajiban (abliyah al-wujub), namun kelayakan tersebut bersifat nisbi dan sangat terbatas. Pada hakikatnya kelayakan tersebut terletak pada pemegang saham, bukan pada badan hukum itu sendiri; 2) badan hukum bukanlah mukalaf, karena badan hukum tidak memenuhi syarat taklif, baik dari segi abliyah al-wujub, apalagi dari segi abliyah al-ada; 3) kedudukan badan usaha swasta dalam bentuk badan hukum adalah bersifat mewakili kepentingan pribadi pemiliknya, baik secara perorangan maupun secara bersama-sama. ${ }^{46}$

Berdasarkan argumen tersebut, apabila pada pemilik badan usaha telah terpenuhi syarat-syarat wajib zakat,

${ }^{46}$ Abdurrahman Dahlan, "Kewajiban Zakat Badan Hukum Perusahaan", h. 9. 
antara lain: pemilik badan usaha beragama Islam, cukup nisab, haul dan kepemilikan sempurna, maka kepada pemilik badan hukum usaha tersebut dikenakan kewajiban zakat. Tindakan hukum menunaikan kewajiban zakat yang dilakukan badan usaha swasta, sebenarnya mewakili tindakan hukum pemiliknya.

Zakat yang ditunaikan oleh badan usaha swasta yang memenuhi syarat wajib zakat, diperhitungkan sebagai penunaian kewajiban zakat pemiliknya, sebatas kekayaannya yang terdapat pada badan usaha tersebut. Dengan demikian, jika pemilik badan usaha memiliki kekayaan lain di luar badan usaha tersebut yang memenuhi syarat-syarat wajib zakat, kekayaan tersebut masih dikenakan kewajiban zakat. Sebaliknya, pemilik badan usaha tidak boleh dikenakan kewajiban zakat ganda, di mana setelah badan usaha tersebut dikenakan kewajiban zakat, pemilik perusahaan masih dikenakan kewajiban zakat atas kekayaan yang dimilikinya pada perusahan tersebut.

\section{Penutup}

Berdasarkan pembahasan tersebut, disimpulkan bahwa lembaga keuanagn syariah pada prinsipnya telah memenuhi standar pengelolaan CSR yang diamanatkan Undang-Undang Perbankan Syariah No 21 tahun 2008. Model pelaksanaan CSR yang dilakukan oleh Bank Syariah Mandiri dan Bank Muamalah melalui lembaga mitra, BSM dengan Lazis BSM dan BMI dengan Baitul Maal Muamalat.

Walaupun terdapat perbedaan pendapat tentang kewajiban zakat perusahaan, BSM menjalankan kewajiban dengan mengalokasikan zakat perusahaan sebesar 2,5\% dari laba sebelum pajak, dan memasukan entitas perusahaan dalam sistem laporan keuangan.

\section{Pustaka Acuan}

Afzalurrahman, Muhammad Sebagai Seorang Pedagang. Jakarta: Penerbit Yayasan Swarna Bhumy, 1997.

Ahmad, Mustaq, Etika Bisnis dalam Islam, Jakarta: Pustaka Al-Kautsar, 2006.

Ahmad Zarqa, Mustafa, al-Fiqh al-Islamy Fi Tsawubihi al-Jadid, Damaskus: Dar al- Fikr,1968.

Bank Muamalah Indonesia, "The Great Leap Forward", Laporan Tahunan 2012.

Chapra, Umer, Islam dan Pembangunan Ekonomi. Jakarta: Gema Insani Press, 2000.

Dahlan, Abdurrahman, "Kewajiban Zakat Badan Hukum Perusahaan", Makalah

Diskusi Dosen FSH 2013.
Hafidhuddin, Didin, Zakat dalam Perekonomian Modern, Jakarta: Gema Insani, 2002

Moleong, Lexy J., Metode Penelitian Kualitatif, Bandung: PT Remaja Rosda, 2002.

Kartajaya, Hermawan dan Muhammad Syakir Sula, Syariah Marketing. Bandung: Mizan, 2006.

M.M. Metwally, Teori dan Model Ekonomi Islam, Jakarta: PT Bangkit Jaya Insana, 1995.

Muhammad, Etika Bisnis Islami. Yogyakarta: UPP AMP YKPN, 2004.

Muhammad dan R Lukman Fauroni, Visi Al-Qur'an tentang Etika dan Bisnis. Jakarta: Salemba Diniyah, 2002.

Muslim, Imam, Shahih Muslim, Beirut: Dar Ihya' AtTurats Al-Arabi. t.th.

Nawab, Syeh Naqvy, Etika dan Ilmu Ekonomi Suatu Sintesa Islam, Bandung: Mizan 1996.

Nursahid, Fajar, Tanggung Jawab Sosial BUMN: Analisis terhadap Model Kedermawanan Sosial PT Krakatau Steel, PT Pertamina, dan PT Telekomunikasi Indonesia, Depok: Piramedia, 2006.

PT Bank Syariah Mandiri, "Grater Ways fo Greater Indonesia” Laporan Tahunan 2012.

Poerwanto, Budaya Perusahaan, Yogyakarta: Pustaka Pelajar, 2008.

al-Qardhawi, Yusuf, Islam Agama Ramah Lingkungan. Jakarta: Pustaka Al-Kautsar, 2002.

, Norma dan Etika Ekonomi Islam. Jakarta: Gema Insani, 1997.

, Hukum Zakat, Jakarta; Litera Antarnusa, 1993.

Rahman, Afzalur Doktrin Ekonomi Islam, Yogyakarta: Dana Bhakti Wakaf, 1995

Siddiqi, Muhammad Nejatulla, Kegiatan Ekonomi dalam Islam. Jakarta: Balai Pustaka, 2004.

Sukirno, Sadono. dkk., Pengantar Bisnis. Jakarta: Prenada Media, 2004.

Soemitra, Andri, Bank dan Lembaga Keuangan Syariah, (Jakarta: Kencana Pranada, 2009

Suharto, Edi, "Audit CSR", Majalah Bisnis dan CSR, Vol.1 (April 2008).

Solihin,Ismail Corporate Social Responsibility, from Charity to Sustainability, Jakarta : Salemba Empat, 2008

Sukirno Sadono, Pengantar Teori Mikro Ekonomi, Jakarta: PT Raja Garfindo Persada, 2002

Susanto, A. B., A Strategic Management Approach CSR, Jakarta: The Jakarta Consulting Group, 2007. 
240 Ahkam: Vol. XVI, No. 2, Juli 2016

Tunggal, Amin Widjaja, Corporate Social Responsibility. Jakarta: Harvarindo, 2008.

Wibisono, Yusuf, Membedah Konsep dan Aplikasi CSR, Cet. II. Gresik: Fascho Publishing, 2007.
al-Zuhaylî Wahbah, Figh Islam wa Adillatuhu, Beirut: Dar Al-Fiqh al-Muashr, 1997.

, Zakat Kajian Berbagai Mazhab, Diterjemahkan oleh Agus Effendi, Bandung: PT Remaja Rosdakarya, 1997 